\title{
Assessment of Western taiga habitat in Lahemaa National Park, Estonia
}

\author{
Teele Paluots ${ }^{1 *}$, Jerry F. Franklin ${ }^{2}$, Lembit Maamets ${ }^{3}$, Diana \\ Laarmann $^{1}$, Ahto Kangur ${ }^{1}$ and Henn Korjus ${ }^{1}$
}

Paluots, T., Franklin, J.F., Maamets, L., Laarmann, D., Kangur, A., Korjus, H. 2018. Assessment of Western taiga habitat in Lahemaa National Park, Estonia. - Forestry Studies | Metsanduslikud Uurimused 69, 44-62, ISSN 1406-9954. Journal homepage: http://mi.emu.ee/ forestry.studies

\begin{abstract}
Diverse structural elements play an important role in sustaining biodiversity in oldgrowth forests. Therefore, it is important to have thorough knowledge about these habitats and their condition in protected areas. Metsakorralduse Büroo OÜ conducted a large-scale Natura 2000 forest habitat inventory that covered $60 \%$ of Lahemaa National Park (LNP) area. Western taiga habitat data $(7,191 \mathrm{ha})$ from this inventory was used for analysis of forest stages. The data was grouped according to stand classes by total area and these classes were compared by deadwood occurrence and relative density. For more precise evaluation of coarse woody debris (CWD) we used 27 sample plots from the Estonian Network of Forest Research Plots (ENFRP) located in LNP. The biggest areas of Western taiga habitat were covered by mature and old stages. CWD occurrence (over $5 \mathrm{~m}^{3} \mathrm{ha}^{-1}$ of snags and logs) by habitat representativeness is higher in old and natural forest classes. This logical result is overshadowed by the outcome that the CWD was not substantially present on $32 \%$ of the area in the old-growth forest class. This indicates that these areas lack the potential of biological legacies to provide critical niche habitats for different species. The study shows that the CWD quantity in Estonian conditions is similar to that reported in previous studies in this region, but because many of the older forest stage classes do not have any CWD present, these areas should include ecological restoration practices in their conservation planning. By creating snags, logs and gaps in these areas, we are able to create better structural variability and include wood into different decay processes.
\end{abstract}

Key words: Natura 2000 network, nature conservation, boreal forest, coarse woody debris, ecosystem legacies.

Authors` address: ${ }^{1}$ Chair of Forest Management Planning and Wood Processing Technologies, Institute of Forestry and Rural Engineering, Estonian University of Life Sciences, Kreutzwaldi 5, 51006 Tartu, Estonia; ${ }^{2}$ School of Environmental and Forest Sciences, University of Washington, Seattle, WA, United States; ${ }^{3}$ Metsakorralduse Büroo OÜ, Puiestee 2, Sõmeru 44201, Lääne-Virumaa, Estonia; *e-mail: teele.paluots@emu.ee

\section{Introduction}

The concept of biological legacies (Franklin et al., 2007) is based on Clements' concept of organic residuals (Clements, 1916) that remain from a pre-disturbance ecosystem and have positive influence on the recovery processes of the post-disturbance ecosystem (Franklin et al., 2000). Providing for diverse structural elements, e.g. canopy gaps and deadwood, and biologically created patterns are important goals in ecological forestry (Franklin et al., 2007). Biological legacies include persistent organisms, organic matter and diverse spatial patterns in an ecosystem. Many biological legacies strongly impact an ecosystem for a short time period after a disturbance 
and subsequently decline in importance due to different natural processes. Structural legacies lifeboat species that would otherwise disappear from a disturbed site by providing critical habitat (e.g., dens and hiding places), substrate (e.g., in the case of epiphytes), and nutrient sources. Standing dead and downed trees are excellent examples of such lifeboats in forested ecosystems. In a less direct manner, structural legacies (both living and dead) also promote survival and re-establishment of organisms by moderating microclimatic conditions in the disturbed area (e.g., shade and reduced temperature extremes) and providing protection from predators (Franklin et al., 2000).

Classification systems using forest developmental stages with transitional events between the stages remediate both concerns of public comprehension and succession by clarifying the successional state and trajectory of forests in conservation areas as well as characterizing the habitat group to which they belong. To add further utility to this system it is useful to consider biological legacies. These are biological elements of an ecosystem left behind after a disturbance such as standing and downed logs or surviving trees as the material legacies (Jõgiste et al., 2017). The presence or absence of biological legacies in older forests provides evidence about previous land management and can indicate the type of treatments needed for ecological restoration, such as activities to provide future biological legacies.

Specific silvicultural actions bring out the three main principles of ecological forestry (continuity, complexity (including heterogeneity), and ecologically-grounded intervention intervals) and fulfill the goal of linking the natural variation of these forests to the wide set of management goals. Variable density thinning approaches promote the development of multiple-age tree groups and maintain forest continuity at the stand scale over time. Moreover, when larger openings are cut in these forests, leg- acy patches are retained within openings to lifeboat species and structures, such as large cavity trees, to enrich newly regenerating openings (Franklin et al., 2018).

Nature reserves are currently the cornerstone to the forest ecosystem conservation effort but problematic when used as the sole biological conservation strategy (Lindenmayer \& Franklin, 2002). Therefore, analysis of their current condition and direction of change is crucially important for future nature conservation development and management goals. If we map forest types in different ownerships status and assess natural representativeness of these areas, we can provide additional clarity to the extent of off-reserve conservation and types of management activities required for achieving larger-scale goals (Lindenmayer et al., 2006).

Natura 2000 is a network of nature conservation areas in the European Union with an objective to ensure the long-term survival of valuable and threatened species and habitats in Europe, listed under Council Directive 2009/147/EC for birds and Council Directive 92/43/EEC for habitats and species protection. The largest proportion $(72,171$ ha, constituting $35 \%$ of forest habitats) of Natura 2000 protected forest habitats in Estonia belongs to Western taiga type (Habitat type *9010) (EELIS, 2016).

Natural forest classifications are often used as references for achieving management goals in protected forest areas. Different classification systems defining forest site types (Lõhmus, 1984), forest vegetation types (Paal, 1997), Natura 2000 habitats (Palo, 2010) in addition with forest survey guidelines (Metsakorraldus, 2009), Forest Act (Metsaseadus, 2006) and Nature Conservation Act (Looduskaitseseadus, 2004) are used in Estonia.

Large-scale forest inventories show how forest types in different habitats and age classes are present in landscapes. In this study we analyzed large-scale habitat inventory data, including the representation of old forest types by considering 
levels of forest development and levels of biological legacies. We were interested in determining how we can apply different stand development classifications to Estonian forest conditions and the effects of coarse woody debris (CWD) presence on Western taiga habitat quality.

\section{Material and methods}

\section{Study area}

The study area is situated in Lahemaa National Park (LNP) in Northern Estonia $\left(59^{\circ} 56^{\prime} \mathrm{N}, 2^{\circ} 77^{\prime} \mathrm{E}\right)$ in the hemiboreal vegetation zone (Figure 1). LNP was established in 1971 and its territory is $473 \mathrm{~km}^{2}$ of land and $275 \mathrm{~km}^{2}$ of sea and waterbodies (Envi- ronmental Register, 2017). Northern Estonian forest flora is not very diverse and the majority of them are dry boreal, heath and ombrotrophic bog forests (Kalda, 1988). The study area $(27,206 \mathrm{ha})$ is based on the Natura 2000 forest inventory (Maamets, 2012) that covered $60 \%$ of the LNP forests. The inventory was conducted by Metsakorralduse Büroo OÜ in 2010-2011.

The main coniferous tree species in the study area were Scots pine (Pinus sylvestris L.) and Norway spruce (Picea abies (L.) Karst.) and deciduous species included birches (Betula pendula Roth. and B. pubescens Ehrh.), European aspen (Populus tremula L.) and black alder (Alnus glutinosa (L.) Gaertn.).

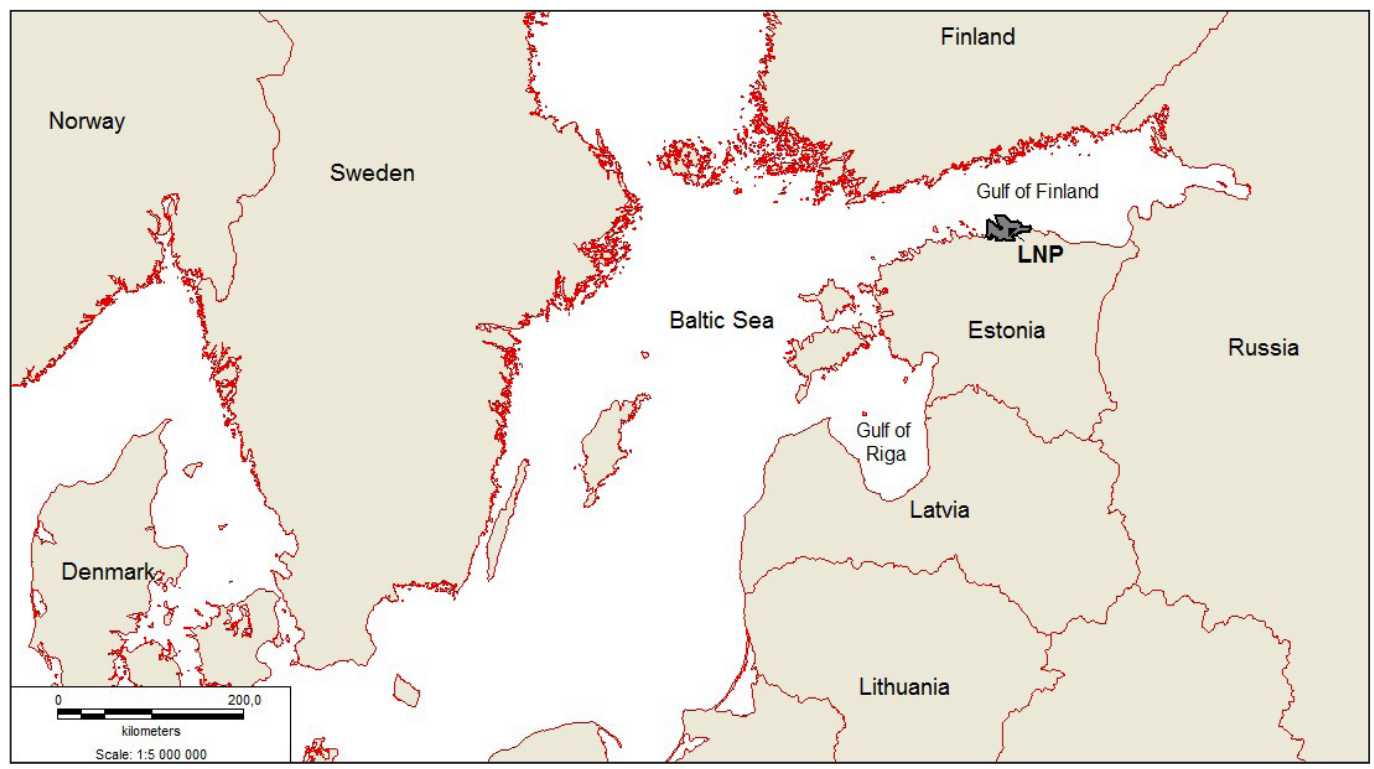

Figure 1. Location of the study area (LNP), Lahemaa National Park, Estonia.

Joonis 1. Uuringuala asukoht (LNP), Lahemaa rahvuspark, Eesti.

The territory of the study area is divided into the following protection categories according to protection regimes: strict nature reserve, special management zones and restricted management zone (Table 1). The goal of a strict nature reserve is to allow ecosystem development through natural processes and exclusion of direct human influence. The goals of a special management zone are to allow ecosystem development through natural processes, protect current Natura 2000 habitat types, and reserve habitat for protected species and to sustain natural biodiversity, landscape 
appearance, ecosystem types and their specific species and age. The goals of a restricted management zone are to protect cultural heritage landscapes, including traditional settlements, historic scenery and landscapes, farm architecture, historical- cultural value buildings and Natura 2000 and protected species habitats. All these goals vary by their protection zones that are set by protection regulations of LNP (Lahemaa, 2015).

Table 1. Protective zones in the study area.

Tabel 1. Uuringuala jaotumine kaitsevööndite järgi.

\begin{tabular}{lccc}
\hline $\begin{array}{l}\text { Protective zone } \\
\text { Kaitsevöönd }\end{array}$ & $\begin{array}{c}\text { Total area (ha) } \\
\text { Kogupindala (ha) }\end{array}$ & $\begin{array}{c}\text { Forest area (ha) } \\
\text { Metsade pindala (ha) }\end{array}$ & $\begin{array}{c}\text { Forest area share (\%) } \\
\text { Metsade osatähtsus (\%) }\end{array}$ \\
\hline $\begin{array}{l}\text { Strict nature reserve } \\
\text { Loodusreservaat }\end{array}$ & 118 & 116 & 98 \\
$\begin{array}{l}\text { Special management zone } \\
\text { Sihtkaitsevöönd }\end{array}$ & 17,736 & 15,536 & 88 \\
$\begin{array}{l}\text { Restricted management zone } \\
\text { Piiranguvöönd }\end{array}$ & 9,352 & 4,507 & 48 \\
\hline $\begin{array}{l}\text { Total } \\
\text { Kokku }\end{array}$ & 27,206 & 20,159 & 74 \\
\hline
\end{tabular}

The most widely distributed forest habitats in LNP are Western taiga at 74\% and Bog woodlands at $13 \%$, based on the inventory that covered $60 \%$ of the park forests (Table 2). All other forest habitats constitute less than $10 \%$.

Table 2. Distribution of the study area in accordance with Natura 2000 forest habitat types. An asterisk (*) indicates a priority habitat.

Tabel 2. Uuringuala jaotumine Natura 2000 metsaelupaigatüüpide järgi. Tärniga (*) on märgitud prioriteetsed elupaigatüübid.

\begin{tabular}{llcc}
\hline \multicolumn{1}{c}{$\begin{array}{c}\text { Natura 2000 habitat type } \\
\text { Natura 2000 elupaigatüüp }\end{array}$} & $\begin{array}{c}\text { Area (ha) } \\
\text { Pindala (ha) }\end{array}$ & $\begin{array}{c}\text { Share (\%) } \\
\text { Osatähtsus (\%) }\end{array}$ \\
\hline 9010 & * Western taiga & 7,846 & 73.8 \\
$91 \mathrm{D0}$ & * Bog woodland & 1,426 & 13.4 \\
9080 & $\begin{array}{l}\text { Fennoscandian deciduous swamp woods } \\
9050\end{array}$ & $\begin{array}{l}\text { Fennoscandian herb-rich forests with } \\
\text { Picea abies }\end{array}$ & 875 \\
$91 \mathrm{E0}$ & $\begin{array}{l}\text { * Alluvial forests with Alnus glutinosa and Fraxinus } \\
\text { excelsior (Alno-Padion, Alnion incanae, Salicion } \\
\text { albae) }\end{array}$ & 289 & 2.7 \\
9060 & $\begin{array}{l}\text { Coniferous forests on, or connected to, glaciofluvial } \\
\text { eskers }\end{array}$ & 165 & 1.5 \\
9020 & $\begin{array}{l}\text { * Fennoscandian hemiboreal natural old broad-leaved } \\
\text { deciduous forests (Quercus, Tilia, Acer, Fraxinus or } \\
\text { Ulmus) rich in epiphytes }\end{array}$ & 18 & 0.2 \\
\hline Total & Kokku & 17 & 0.2 \\
\hline
\end{tabular}


This study focuses on the Western taiga habitat type as it plays the key role in the Natura 2000 network in Estonia. The term "taiga" is broadly used in ecological literature and can be defined as a coniferous northern forest with no admixture of deciduous species, except birch and aspen (Ritchie, 1962; Larsen, 1980, 1982). According to Palo (2010), these forests may be influenced by human activities, but must include very specific old-growth attributes like gaps and groups of standing dead and downed trees, nursery logs, and variable age structure. Forests recovering from fires and storms are also included in this habitat type. These disturbances create gaps of varied sizes that include snags and logs which can provide habitat, substrate and food sources to different species. These disturbed areas also provide the youngest forest developmental stages in natural areas.

\section{Sampling and measurements}

The sampling unit for Natura 2000 forest habitats inventory was the forest stand. For field inventory the Forest survey guidelines (Metsakorraldus, 2009) were used and stand characteristics were assessed for the main canopy (I), sub-canopy (II), regeneration (R) and shrub (S) layer and determinations of average age, height, diameter at breast height (DBH) of trees. All forest stands in different habitats with over $5 \mathrm{~m}^{3} \mathrm{ha}^{-1}$ snags (standing deadwood) and over $5 \mathrm{~m}^{3} \mathrm{ha}^{-1}$ logs (lying deadwood) were used for CWD assessment. Main canopy consisted of taller trees, the species composition of which was assessed by share according to the layer volume. II tree layer included trees that were between 25 to $75 \%$ of the average height of I tree layer (not counting high Corylus avellana L. but including Salix and Sorbus trees). The S layer includes all shrub species (including e.g., Corylus avellana L. or Frangula alnus Mill.) up to $8-10 \mathrm{~m}$ in height. $\mathrm{R}$ layer (regeneration) trees are all the seedlings and trees lower than II layer (including Salix, Sorbus and Prunus padus L. trees).

Analyzed data is collected in LNP as a part of the Natura 2000 forest habitat inventory that was conducted in 2010-2011 (Maamets, 2012). All the collected forest inventory data was merged with Palo's (2010) classification and the results were used to analyze forest stages (See section 2.3.). Then the data was grouped by total area (ha) into stand classes and these were compared by deadwood occurrence and coverage percent (\%) of sub-canopy (II) and regeneration $(\mathrm{R})$ layer trees.

For more precise evaluation of CWD and its level of decomposition we used 27 sample plots from the Estonian Network of Forest Research Plots (ENFRP) located in LNP. The ENFRP plots are circular and plots consist of 59-387 (average 194) trees from the canopy layer. Plot radius varies between 20-30 m. On these plots Scots pine is the dominant tree species and site type varies from heath to dry boreal (Cladonia, Rhodococcum and Myrtillus site types). Twenty-five sample plots were established in 1998 and have been re-measured three times with five-year intervals (in 2003, 2008 and 2013), two of the plots were first measured in 2002 and have been re-measured three times at five-year intervals (in 2007, 2012 and 2017). According to the ENFRP survey protocol (Kiviste et al., 2015), the stem location and DBH are recorded for all trees with a diameter larger than 4 $\mathrm{cm}$. Also data on snags and regeneration is collected.

\section{Classification and analyses}

The Forest Act (Metsaseadus, 2006) of Estonia determines the minimum allowable regeneration cutting ages (criteria for mature stands) for deciduous- and conifer-dominated forests depending on the site quality and tree species composition. In silver birch and black alder stands the allowable cutting age differs depending on the site quality and ranges from 60 to 80 years and in European aspen stands from 30 to 50 years. In mature stands of 
Norway spruce the range is from 60 to 120 years and in Scots pine stands from 90 to 160 years. In previously managed forests the natural developmental processes may take longer before the old forest attributes start to develop. By comparing forest stand development stages with the Forest Act (Metsaseadus, 2006) and the Habitats Directive forest habitat inventory guide (Palo, 2010) to typical stage ages, we infer that forest should be older than allowable cutting ages to have developed the vertical and horizontal diversification stages that characterize early old-growth forest conditions. The forest development stages were compared and integrated into Franklin et al. (2018) classification. The typical stage year classes (Appendix 1) were defined by average stand age and dominant tree species in the canopy layer.

For analyses of CWD we divided inventory data and ENFRP according to their habitat representativeness (Palo, 2010) into four groups: OG - old-growth stand, developed continuously without management signs; $\mathrm{N}$ - natural stand with all structural elements, mostly a sufficiently old and sustainably developing forest with some minor management signs; REC - recovering stand, because of earlier management some structural elements can be missing or moderately represented, but at the moment the stand has been developing continuously; POT - potential stand that has the possibility of developing into a Natura 2000 habitat in the future depending on management planning. The LNP Western taiga habitat type data met the criteria of the representativeness class on 7,191 ha; data for areas that did not meet the representativeness class criteria (655 ha) were excluded from current analyses.

\section{Results}

LNP Natura 2000 forest inventory shows the largest share of mature and early old forest stages. By comparing dominant tree species and deadwood occurrence for typical stage years (Appendix 1) we can see also the features these stands contain by area (Table 3). Except the first stage, most of these classes have substantial deadwood present.

Forests that reach maturity after having been planted usually will have an understory, but other important attributes of oldgrowth (snags, logs, etc.) are not well present. That is why the age of vertical (early old forest) and horizontal diversification (late old forest) in Appendix 1 is set higher than the mature stand age as defined in the Forest Act (Metsaseadus, 2006). When grouping these forests by I layer tree species the greatest areas are in mature and early old-growth forest classification groups. The occurrence of deadwood is highest in older forest development stages but it is still not present in $25 \%$ of the areas. In young forest stages 33-40\% of the areas lacked CWD (Table 3).

The highest proportion of II layer trees in forests dominated by Norway spruce is in the mature age class, while the Scots pine and deciduous regeneration (R) layer occurs mostly in the old forest stage (Table $4)$. In young forests the cover of the regeneration layer is low, from a trace up to $17 \%$. The majority of II layer in deciduous-dominated forest is Norway spruce, indicating the natural successional shift away from old deciduous forest to conifer-dominated systems. In forests dominated by Norway spruce and Scots pine the II layer is also Norway spruce, demonstrating the first signs of vertical diversification. However, the amount of regeneration in deciduous forests is relatively low. The lower number for the deciduous forest may reflect low numbers of gaps in this forest type, which would provide more horizontal diversification for these areas.

CWD occurrence (over $5 \mathrm{~m}^{3} \mathrm{ha}^{-1}$ of snags and logs) by habitat representativeness is higher in OG and $N$ classes (Table 5). This result is limited by the fact that CWD was not present in substantial amounts on $32 \%$ 
of area in the old-growth forest class (OG). This indicates that these areas lack critical niche habitats for different species that would otherwise be expected in older forest.

In LNP the dry boreal is the most wide- spread site type group in Western taiga habitat. This site type provides the highest areas in all representability classes (Table 6). Most of the stands are present in good and average representability classes.

Table 3. Different stages of Western taiga habitats according to the dominant tree species in the study area. Typical stage years are according to species groups in Appendix 1 and classification by Franklin et al. (2018).

Tabel 3. Vanade loodusmetsade elupaigatüübi puistute jaotus arenguklassidesse uuringualal enamuspuuliigi järgi. Arenguklasside tüüpilised vanused enamuspuuliikide kaupa on esitatud lisas 1 ja arenguklasside klassifikatsioon on Franklin et al. (2018) järgi.

\begin{tabular}{|c|c|c|c|c|c|c|c|c|}
\hline \multirow[t]{2}{*}{$\begin{array}{l}\text { Stage class } \\
\text { Arenguklass }\end{array}$} & \multirow[t]{2}{*}{$\begin{array}{c}\text { Total area } \\
\text { Kogu- } \\
\text { pindala } \\
\text { (ha) }\end{array}$} & \multicolumn{5}{|c|}{$\begin{array}{l}\text { Area (ha) by dominant tree species } \\
\text { Pindala (ha) enamuspuuliigi järgi }\end{array}$} & \multicolumn{2}{|c|}{$\begin{array}{l}\text { Deadwood } \\
\text { occurrence } \\
\text { Lagupuidu } \\
\text { esinemine }\end{array}$} \\
\hline & & $\begin{array}{c}\text { Norway } \\
\text { spruce } \\
\text { Harilik } \\
\text { kuusk }\end{array}$ & $\begin{array}{l}\text { Scots } \\
\text { pine } \\
\text { Harilik } \\
\text { mänd }\end{array}$ & $\begin{array}{l}\text { Silver } \\
\text { birch } \\
\text { Arukask }\end{array}$ & $\begin{array}{c}\text { Black } \\
\text { alder } \\
\text { Sanglepp }\end{array}$ & $\begin{array}{c}\text { European } \\
\text { aspen } \\
\text { Harilik } \\
\text { haab }\end{array}$ & $\begin{array}{c}\text { Snags } \\
\text { Surnud } \\
\text { puud } \\
(\%)\end{array}$ & $\begin{array}{l}\text { Logs } \\
\text { Lama- } \\
\text { puit } \\
(\%)\end{array}$ \\
\hline $\begin{array}{l}\text { Disturbance and } \\
\text { legacy creation }\end{array}$ & 0.6 & 0.0 & 0.6 & 0.0 & 0.0 & 0.0 & 100.0 & 0.0 \\
\hline Pre-forest & 9.4 & 2.0 & 1.1 & 6.3 & 0.0 & 0.0 & 100.0 & 100.0 \\
\hline Canopy closure & 9.4 & 8.1 & 0.0 & 0.8 & 0.5 & 0.0 & 53.2 & 100.0 \\
\hline Young forest & 167.8 & 17.2 & 136.8 & 8.7 & 2.6 & 2.5 & 60.8 & 60.1 \\
\hline Mature forest & 2871.7 & 258.5 & 2470.0 & 118.6 & 11.7 & 12.9 & 61.0 & 66.4 \\
\hline $\begin{array}{l}\text { Old forest (Early } \\
\text { stage) }\end{array}$ & 3716.3 & 1161.7 & 2465.0 & 66.7 & 19.7 & 3.5 & 63.8 & 65.5 \\
\hline $\begin{array}{l}\text { Old forest (Late } \\
\text { stage) }\end{array}$ & 413.3 & 87.6 & 124.6 & 147.1 & 39.9 & 14.1 & 64.4 & 74.4 \\
\hline
\end{tabular}

Table 4. Relative frequency (\%) of sub-canopy (II) and regeneration (R) layers at inventoried Western taiga habitats according to dominant canopy (I) layer tree species.

Tabel 4. Puistu II rinde (II) ja järelkasvu rinde (R) suhteline esinemissagedus vanade loodusmetsade elupaigatüübis uuringualal I rinde enamuspuuliigi järgi.

\begin{tabular}{lccccccc}
\hline $\begin{array}{l}\text { Stage class according to Franklin et al. (2018) } \\
\text { Arenguklass Franklin et al. (2018) järgi }\end{array}$ & \multicolumn{2}{c}{$\begin{array}{c}\text { Norway spruce } \\
\text { Harilik kuusk }\end{array}$} & $\begin{array}{c}\text { Scots pine } \\
\text { Harilikmänd }\end{array}$ & \multicolumn{2}{c}{$\begin{array}{c}\text { Deciduous } \\
\text { Lehtpuud }\end{array}$} \\
\cline { 2 - 7 } & $\mathrm{II}$ & $\mathrm{R}$ & $\mathrm{II}$ & $\mathrm{R}$ & $\mathrm{II}$ & $\mathrm{R}$ \\
\hline Young forest & 9 & 17 & 37 & 11 & 41 & 0 \\
Mature forest & 97 & 34 & 48 & 20 & 63 & 7 \\
Old forest (Early stage) & 42 & 52 & 58 & 38 & 78 & 16 \\
\hline
\end{tabular}


Table 5. Occurrence of CWD (over $5 \mathrm{~m}^{3} \mathrm{ha}^{-1}$ of snags and logs) and average stand age in Western taiga habitat representativeness classes. Representativeness classes: OG - old-growth, $\mathrm{N}$ - natural, REC - recovering and POT - potential stand.

Tabel 5. Lagupuidu esinemine (üle $5 \mathrm{~m}^{3} \mathrm{ha}^{-1}$ püstiseisvaid surnud puid ja lamapuitu) ja puistute keskmine vanus vanade loodusmetsade elupaigatüübi puistutes esindusklasside järgi. Esindusklassid: OG - põlismets, N-loodusmets, REC - taastuv mets, POT - potentsiaalne elupaik.

\begin{tabular}{lccc}
\hline $\begin{array}{l}\text { Occurrence of CWD } \\
\text { Lagupuidu esinemine }\end{array}$ & $\begin{array}{c}\text { Area (ha)/percentage } \\
\text { Pindala (ha)/osakaal }\end{array}$ & $\begin{array}{c}\text { Average stand age (years) } \\
\text { Puistute }\end{array}$ \\
\hline OG & 707 ha & 128 \\
& No & $32 \%$ & 137 \\
& Yes & $68 \%$ & 123 \\
N & & 3,547 ha & 129 \\
& No & $41 \%$ & 132 \\
& Yes & $59 \%$ & 125 \\
REC & & 2,914 ha & 119 \\
& No & $50 \%$ & 121 \\
& Yes & $50 \%$ & 118 \\
POT & 23 ha & $87 \%$ & 120 \\
& No & $13 \%$ & 118 \\
& Yes & & 130 \\
\hline
\end{tabular}


Table 6. Occurrence of Estonian forest site type groups (according to Lõhmus, 1984) in Western taiga habitat representativeness classes. Representativeness classes: OG - old-growth, $\mathrm{N}$ - natural, REC - recovering and POT - potential stand.

Tabel 6. Kasvukohatüübirühmade (Lôhmus, 1984 järgi) esinemine vanade loodusmetsade elupaigatüübi puistutes esindusklasside järgi. Esindusklassid: OG - põlismets, N - loodusmets, REC - taastuv mets, POT - potentsiaalne elupaik.

\begin{tabular}{|c|c|c|c|c|c|}
\hline \multirow[t]{3}{*}{$\begin{array}{l}\text { Site type group } \\
\text { Tüübirühm }\end{array}$} & \multirow[t]{3}{*}{$\begin{array}{c}\text { Site types } \\
\text { Kasvukohatüüp }\end{array}$} & \multicolumn{4}{|c|}{$\begin{array}{c}\text { Area } \\
\text { Pindala (ha) }\end{array}$} \\
\hline & & \multicolumn{4}{|c|}{$\begin{array}{l}\text { Representativeness class } \\
\text { Esindusklass }\end{array}$} \\
\hline & & OG & $\mathrm{N}$ & REC & POT \\
\hline Alvar & $\begin{array}{l}\text { Arctostaphylos-alvar } \\
\text { Calamagrostis-alvar }\end{array}$ & 0 & 0 & 1 & 0 \\
\hline Bog & Ombrotrophic bog, mixotrophic bog & 0 & 12 & 15 & 0 \\
\hline Drained peatland & Drained bog and swamp forests & 17 & 180 & 121 & 0 \\
\hline Dry Boreal & Rhodococcum, Myrtillus & 537 & 2489 & 2045 & 23 \\
\hline Eutrophic boreo-nemoral & Aegopodium, Dryopteris & 3 & 67 & 13 & 0 \\
\hline Eutrophic paludifying & Filipendula, Molina & 2 & 40 & 23 & 0 \\
\hline Heath & Cladonia, Calluna & 89 & 393 & 454 & 0 \\
\hline Meso-eutrophic & Oxalis, Hepatica & 9 & 53 & 46 & 0 \\
\hline Oligotrophic paludifying & V. uliginosum, Polytrcihum & 49 & 307 & 193 & 0 \\
\hline Swamp & $\begin{array}{c}\text { Stagnant-water swamp, mobile-water } \\
\text { swamp }\end{array}$ & 0 & 5 & 4.1 & 0 \\
\hline Total / kokku & & 707 & 3,547 & 2,914 & 23 \\
\hline
\end{tabular}

Table 7. The area of Western taiga habitats according to habitat representativeness classes in different protective zones at study area. Representativeness classes: OG - old-growth, N natural, REC - recovering and POT - potential stand.

Tabel 7. Vanade loodusmetsade elupaigatüübi puistute pindala uuringualal kaitsevööndite ja esindusklasside järgi. Esindusklassid: OG - põlismets, N-loodusmets, REC - taastuv mets, POT-potentsiaalne elupaik.

\begin{tabular}{cccccc}
\hline $\begin{array}{c}\text { Protective zone } \\
\text { Kaitsevö̈nd }\end{array}$ & OG & N & REC & POT & $\begin{array}{c}\text { Total } \\
\text { Kokku }\end{array}$ \\
\cline { 2 - 6 } & 49 & 15 & 0 & 0 & 64 \\
Nature reserves & 621 & 3,270 & 2,442 & 23 & 6,356 \\
Special management zones & 38 & 261 & 472 & 0 & 771 \\
Limited management zones & 708 & 3,546 & 2,914 & 23 & 7,191 \\
\hline Total / kokku & & & & & \\
\hline
\end{tabular}


Table 8. The volume of snags $\left(\mathrm{m}^{3} \mathrm{ha}^{-1}\right)$ in Lahemaa 27 ENFRP in the study area in 5-year periods. Representativeness classes: $\mathrm{N}$ - natural, REC - recovering and POT - potential stand.

Tabel 8. Surnud puude mahu dünaamika $\left(\mathrm{m}^{3} h \mathrm{~h}^{-1}\right) 27$ metsa kasvukäigu püsiproovitükil uuringualal 5-aastaste perioodide kaupa. Esindusklassid: OG - põlismets, $N$-loodusmets, REC-taastuv mets, POT - potentsiaalne elupaik.

\begin{tabular}{|c|c|c|c|c|}
\hline \multirow{2}{*}{$\begin{array}{l}\text { ENFRP } \\
\text { number } \\
\text { Proovitüki } \\
\text { number }\end{array}$} & \multirow[t]{2}{*}{$\begin{array}{c}\text { Habitat } \\
\text { representativeness } \\
\text { Elupaiga esindusklass }\end{array}$} & \multicolumn{3}{|c|}{$\begin{array}{l}\text { Volume of snags } \\
\text { Surnud puude maht } \\
\left(\mathrm{m}^{3} \mathrm{ha}^{-1}\right)\end{array}$} \\
\hline & & $\begin{array}{l}\text { First measurement } \\
\text { Esimene mõotmine }\end{array}$ & $\begin{array}{c}\text { Second measurement } \\
(+5 \text { years }) \\
\text { Teine mõótmine } \\
(+5 \text { aastat })\end{array}$ & $\begin{array}{l}\text { Third measurement } \\
(+10 \text { years }) \\
\text { Kolmas mõõtmine } \\
(+10 \text { aastat })\end{array}$ \\
\hline 736 & $\mathrm{~N}$ & 30.6 & 34 & 30.4 \\
\hline 737 & $\mathrm{~N}$ & 9.6 & 9 & 34.5 \\
\hline 1074 & $\mathrm{~N}$ & 9.4 & 26.6 & 28.4 \\
\hline 1077 & РОТ & 2.6 & 6.3 & 7.9 \\
\hline 1078 & РОТ & 2.4 & 4.9 & 7.8 \\
\hline 1079 & REC & 18.3 & 21.6 & 32.8 \\
\hline 1080 & РОТ & 8.1 & 19.3 & 30.9 \\
\hline 1081 & РОТ & 2.9 & 5.8 & 9.6 \\
\hline 1082 & $\mathrm{~N}$ & 11 & 15.5 & 16 \\
\hline 1084 & $\mathrm{~N}$ & 29.1 & 46.6 & 53.3 \\
\hline 1093 & $\mathrm{~N}$ & 0 & 1.2 & 1.2 \\
\hline 1094 & $\mathrm{~N}$ & 0.7 & 5.2 & 5.2 \\
\hline 1100 & REC & 25.2 & 47.2 & 45.3 \\
\hline 1101 & REC & 5.3 & 26.2 & 31.7 \\
\hline 1102 & REC & 7.6 & 12.1 & 16 \\
\hline 1108 & REC & 2.3 & 9.6 & 20.2 \\
\hline 1113 & РОТ & 5 & 5.9 & 9.3 \\
\hline 1114 & РОТ & 6.6 & 15.2 & 19.2 \\
\hline 1115 & $\mathrm{~N}$ & 3.5 & 5.4 & 6.7 \\
\hline 1116 & $\mathrm{~N}$ & 2.4 & 4.1 & 15.2 \\
\hline 1117 & РОТ & 0.9 & 2.4 & 4.2 \\
\hline 1118 & РОТ & 0.6 & 6.2 & 7.7 \\
\hline 1120 & REC & 6.8 & 8.4 & 15.2 \\
\hline 1121 & REC & 4.3 & 10.7 & 17.3 \\
\hline 1122 & РОТ & 2.9 & 3.1 & 6.8 \\
\hline 1132 & REC & 5.1 & 7.9 & 13.4 \\
\hline 1133 & REC & 12.1 & 18.5 & 22.3 \\
\hline
\end{tabular}


Table 9. Average stand characteristics on pine dominated heath to dry boreal forest habitat type based on ENFRP data of 27 sample plots in the study area. Representativeness classes ( $\mathrm{N}$ natural, REC - recovering and POT - potential stand) are divided by stage ages (Appendix $1): Y$ - young stand (20-90 years), $M$ - mature stand (90-120 years), $0 E$ - old early stage (120-200 years), OL - old late stage (200+ years). SE-standard error.

Tabel 9. Männi enamusega puistute keskmised näitajad nõmme- ja palumetsades 27 metsa kasvukäigu püsiproovitükil uuringualal. Esindusklassid: OG - põlismets, $N$ - loodusmets, REC - taastuv mets, POT - potentsiaalne elupaik, ja arenguklassid vanustega: $Y$ - noor puistu (20-90 aastat), M - küps puistu (90-120 aastat), OE - vana metsa algfaas (120200 aastat), OL - vana metsa hilisfaas (200+ aastat). SE - standardviga

\begin{tabular}{cccc}
\hline $\begin{array}{l}\text { Habitat representativeness/stage } \\
\text { Elupaiga esindusklassja arenguklass }\end{array}$ & $\begin{array}{c}\text { Snags } \\
\text { Surnud puud } \\
\text { ha }^{-1}( \pm S E)\end{array}$ & $\begin{array}{c}\text { I layer diameter } \\
\text { Esimese rinde } \\
\text { diameeter } \\
\text { cm }\end{array}$ & $\begin{array}{c}\text { Age } \\
\text { Vanus (a) } \\
\text { years }\end{array}$ \\
\hline N & $115 \pm 24$ & 25 & 137 \\
Y & $108 \pm 24$ & 23 & 78 \\
M & $181 \pm 57$ & 19 & 103 \\
OE & $102 \pm 38$ & 26 & 156 \\
OL & $7 \pm 3$ & 36 & 238 \\
REC & $312 \pm 38$ & 16 & 79 \\
Y & $293 \pm 38$ & 16 & 76 \\
M & $428 \pm 141$ & 19 & 95 \\
POT & $166 \pm 29$ & 15 & 75 \\
Y & $135 \pm 31$ & 14 & 67 \\
M & $234 \pm 61$ & 16 & 95 \\
\hline Total / kokku & $199 \pm 20$ & 18 & 96 \\
\hline
\end{tabular}

Comparison of Western taiga in different LNP protective zones shows that most of the forests are present in a good stage (e.g., OG and N) in conservation zones (Table 7). The average and potential stages (REC and POT) occur in special and limited management zones which shows that forests in these areas still have room for development. In limited management zones the priority is protection of cultural landscapes and therefore, it can also influence the total area of natural habitats. In the future the focus of restoration should be on special management zone forests with average and potential representation.

If we look at the volume of snags (Table 8) in ENFRP plots in LNP we can see there is lot of variability which is hard to generalize. If natural stands have more snags than potential ones, it is the result of competition and natural succession, because in natural stands these snags have already fallen down. The lower number of snags also reflects the previous management in potential stands. Evaluation of snags and logs can be a good starting point for Western taiga conservation planning in the future, but more knowledge about this variable is still needed. To see how fast snags appear in stands we used ENFRP data after the first 5-year measurement period (Table 8 ). The higher numbers of snags appeared on potential and average stands. This means that these stands are more productive in young forest and early maturing stages (Table 9). Area distribu- 

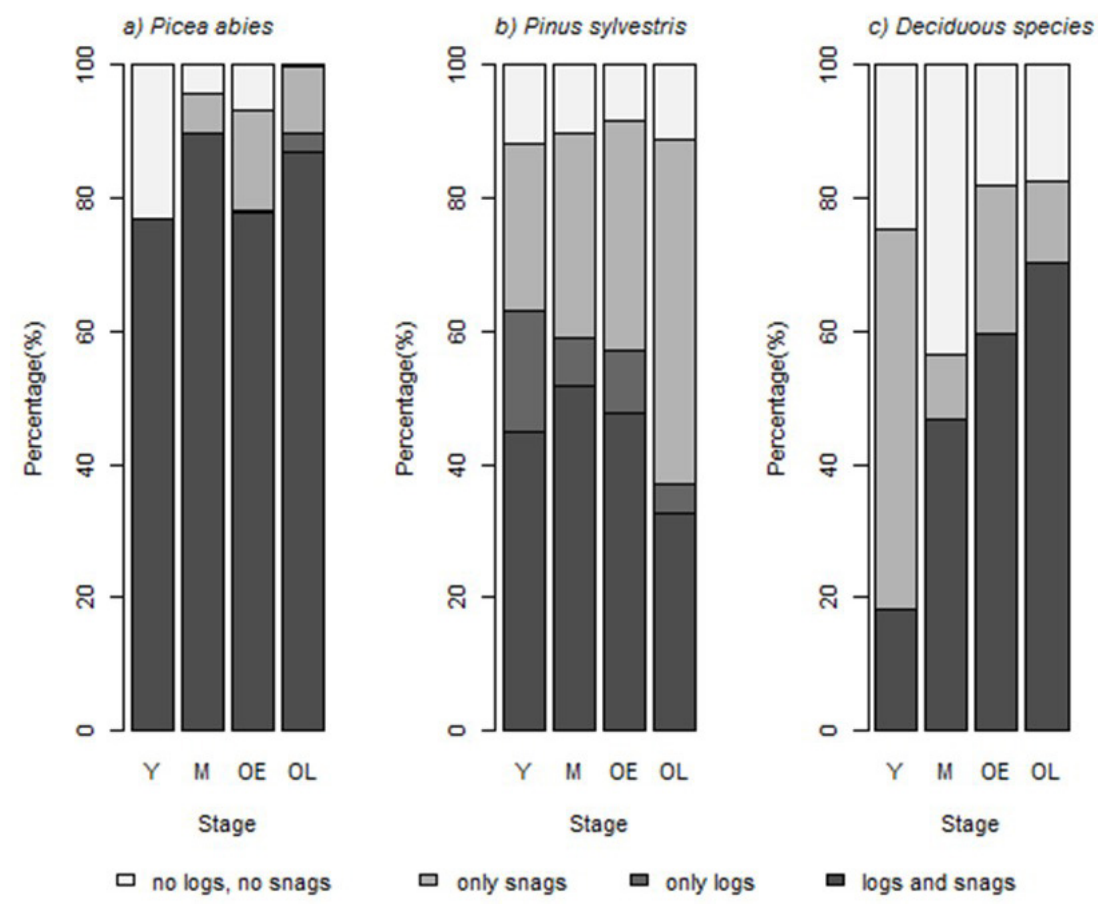

Figure 2. Area distribution of CWD presence in different stages according to dominant tree species in the study area. Logs - downed stems, snags - standing stems.

Joonis 2. Uuringuala pindala jaotumine lagupuidu esinemise ja enamuspuuliigi järgi. Logs - lamapuit, snags - püstiseisvad surnud puud.

tion of CWD presence in different stages according to dominant tree species in the study area (Figure 2) shows more diverse CWD in later stages.

\section{Discussion}

If we compare collected data with literature (Table 10), the CWD volume and density discussed in the current study seem to have similar patterns. The highest con- trast comes out from the data reported by Shorohova \& Kapitsa (2014), where in $100 \%$ Scots pine dominated forests the total CWD volume (47-130 $\mathrm{m}^{3} \mathrm{ha}^{-1}$ ) and Shannon index for the decay class distribution (1.2-2.1) is indicative of higher decomposition rates in these areas. In these pristine forests the availability of substrates in different decay classes seems to be higher than in currently protected areas in Lahemaa and South-Eastern Estonia (Lõhmus \& Kraut, 2010). 
Table 10. CWD characteristics in Scots pine dominated natural ${ }^{1}$ forests in different vegetation zones according to literature. Abbreviations: CWD - coarse woody debris, SE - standard error, SD - standard deviation. Vegetation zones according to Ahti et al. (1968).

Tabel 10. Lagupuidu näitajad hariliku männi enamusega looduslikes metsades erinevates taimkattevööndites vastavalt erinevatele uurimustele. Lühendid: CWD - lagupuit, SE - standardviga, SD - standardhälve. Taimkattevööndid on esitatud Ahti et al. (1968) järgi.

\begin{tabular}{|c|c|c|c|c|c|c|}
\hline $\begin{array}{l}\text { Vegetation zone } \\
\text { Taimkattevöönd }\end{array}$ & $\begin{array}{l}\text { Total CWD } \\
\text { Lagupuit } \\
\left(\mathrm{m}^{3} \mathrm{ha}^{-1}\right)\end{array}$ & $\begin{array}{l}\text { Snags } \\
\text { Surnud } \\
\text { puud } \\
\left(\mathrm{m}^{3} \mathrm{ha}^{-1}\right)\end{array}$ & $\begin{array}{l}\text { Logs } \\
\text { Lamapuit } \\
\left(\mathrm{m}^{3} \mathrm{ha}^{-1}\right)\end{array}$ & $\begin{array}{l}\text { CWD extent } \\
\text { Lagupuidu } \\
\text { arvukus } \\
\left(\mathrm{ha}^{-1}\right)\end{array}$ & $\begin{array}{l}\text { Location } \\
\text { Asukoht }\end{array}$ & $\begin{array}{c}\text { Reference } \\
\text { Kirjandusviide }\end{array}$ \\
\hline Hemiboreal & $\begin{array}{c}18.2 \\
(S E 2.09)\end{array}$ & $\begin{array}{c}9.46 \\
(S E 1.09)\end{array}$ & $\begin{array}{c}8.72 \\
(S E 1.2)\end{array}$ & * & $\begin{array}{c}\text { Lahemaa, } \\
\text { Estonia }\end{array}$ & $\begin{array}{c}\text { Köster et al., } \\
2005\end{array}$ \\
\hline Hemiboreal & $36(S D 29)$ & * & $\begin{array}{c}13.6 \\
(S D 11.8)\end{array}$ & $64(S D 46)$ & SE Estonia & $\begin{array}{c}\text { Lõhmus \& Kraut, } \\
2010\end{array}$ \\
\hline Northern boreal & $\begin{array}{c}18.8(S D \\
11.0)\end{array}$ & $\begin{array}{l}6.6(35.1 \% \\
\text { of CWD) }\end{array}$ & $\begin{array}{c}11.3 \\
\text { (60.1\% of } \\
\text { CWD) }\end{array}$ & * & $\begin{array}{l}\text { Lapland, } \\
\text { Finland }\end{array}$ & $\begin{array}{c}\text { Sippola etal., } \\
1998\end{array}$ \\
\hline $\begin{array}{l}\text { Southern and } \\
\text { middle boreal }\end{array}$ & $\begin{array}{c}14.8 \\
(S D 16.5)\end{array}$ & * & * & $\begin{array}{c}69.0 \\
\text { (total range } \\
35-120 \text { ) }\end{array}$ & $\begin{array}{l}\text { Häme, } \\
\text { Finland }\end{array}$ & \\
\hline Middle boreal & $\begin{array}{c}14.9 \\
(S D 15.3)\end{array}$ & * & * & $\begin{array}{c}124.0 \\
\text { (total range } \\
75-190)\end{array}$ & $\begin{array}{l}\text { Kuhmo, } \\
\text { Finland }\end{array}$ & $\begin{array}{c}\text { Rouvinen et al., } \\
2002\end{array}$ \\
\hline Middle boreal & $0.7(S D 1.0)$ & * & * & $\begin{array}{c}82.1 \\
\text { (total range } \\
45-135)\end{array}$ & $\begin{array}{c}\text { Vienansalo, } \\
\text { Russian } \\
\text { Federation }\end{array}$ & \\
\hline Middle boreal & * & * & * & $\begin{array}{c}169 \\
\text { (34\% of } \\
\text { standing } \\
\text { trees) }\end{array}$ & $\begin{array}{l}\text { Seitseminen, } \\
\text { Finland }\end{array}$ & $\begin{array}{c}\text { Nilsson et al., } \\
2003\end{array}$ \\
\hline Northern boreal & $47-112$ & * & * & * & Russian & Shorohova \& \\
\hline Northern boreal & $81-130$ & * & * & * & & Kapitsa, 2014 \\
\hline $\begin{array}{l}\text { Northern to } \\
\text { southern boreal }\end{array}$ & $\begin{array}{c}22.9 \\
(S E 1.89)\end{array}$ & * & * & * & Sweden & $\begin{array}{c}\text { Jonsson et al., } \\
2016\end{array}$ \\
\hline Hemiboreal & $\begin{array}{c}12.72 \\
(S E 1.12)\end{array}$ & * & * & * & & \\
\hline Hemiboreal & * & $\begin{array}{c}10.0 \\
(S E 3.1)\end{array}$ & * & $\begin{array}{c}81.2 \\
(S E 29.2)\end{array}$ & $\begin{array}{c}\text { Lahemaa, } \\
\text { Estonia }\end{array}$ & Current study \\
\hline
\end{tabular}

${ }^{1}$ Natural is considered as old-growth or pristine forests. For Jonsson et al. (2016) we used the Natura 2000 habitat group "Taiga expanded". Only OE and OL stage classes were included from the current study.

Classical Clementsian plant communities were viewed as complex organisms that go through predictable, developmental changes leading ultimately to a stable climax community (Worster, 1994). Old forest stands give us spiritual and biological values that managed forests cannot provide but do not represent a "stable climax community" as predicted in that paradigm.
These forests are continuing to undergo change as a result of growth, tree senescence and mortality. We cannot determine their ultimate condition but can describe some stages or levels of old-growth development. Old-growth is best understood as a stage of forest development characterized by greater diversity of structures and more heterogeneous arrangements of structures 
than are found in younger successional stages originating after harvests (Thomas et al., 1988). In structural descriptions of old-growth it is important to distinguish between certain features - like having old relatively large trees, several canopy layers, dead trees and logs.

Among boreal tree species, Norway spruce hosts the greatest number of red-listed species (Jonsson et al., 2005; Tikkanen et al., 2006). This is the second most dominant tree species in the canopy layer after Scots pine in Western taiga and the most abundant tree in the regeneration layer. Naturally, rare species are often assumed to depend on some "climax" condition, such as old-growth but in fact may be limited by soil, deadwood, microclimate, disturbance, or other factors (Carey, 2009). The majority of rare species actually seem to require some defined finescale niche. So identifying these niches in old-growth forests provides us with the opportunity to restore them in even-aged, pre-managed forests. One way to do this is to create more snags, logs and gaps. A major part of the lifeboating functions for species are typically provided by larger biological structures that persist following a disturbance, such as live trees, snags and downed boles (Franklin et al., 2007). Also different restoration treatments increase the deadwood input and heterogeneity in a stand (Laarmann et al., 2013). By incorporating biological legacies into harvest prescriptions it is possible to increase the proportion of many different tree species and tree snags and thereby increase the occurrence of niches required by threatened species.

Conservation planning can set the goal of old-growth, but can we actually achieve the state as it was historically? Much more than half of forests have been influenced by human management activities in one way or another and their ability to recover to their historical natural condition is unknown. It is hard to determine the historical stage of previously managed forests and set the conservation goals according to historical stage. Köster et al. (2005) determine that areas in Lahemaa, which had been clear-cut at the beginning of the twentieth century, had lower volume of CWD than areas that were thinned or not managed. We do not always know if previous activities by humans have changed the forest ecosystem resilience in a way that makes the return to "historical" through natural processes impossible. Forest ecosystems may have shifted to a different stable state resulting in the question of whether we should attempt to restore them to their previous state or sustain them in their current state.

The issue of biodiversity also emerges when we talk about different habitats in conservation areas. The main forest habitat type in Lahemaa National Park is overwhelmingly considered as Western taiga. If we are concerned about biodiversity it will be important to improve the conditions and representation of other habitats. For example, there were no wooded pastures and only 6 ha of old broad-leaved deciduous forests in Lahemaa National Park. Lindenmayer et al. (2006) note that forest types that are poorly protected in a reserve system will need to be managed differently than forest types already well represented in reserves. Underwood et al. (2014) advised that passive management in the US will realize slower growth rates, and accordingly slower development of complex forest structures associated with biodiversity and recovery of the Northern Spotted Owl. Lastly, passive management would also slow the creation of openings dominated by a variety of plant life forms, which in many forest landscapes actually have the highest levels of biological diversity (Swanson et al., 2011). To summarize, there may be the need to enlarge the areas of other forest habitats that are poorly represented or absent in the current landscape but which would enrich the overall diversity of forest habitats.

Integrated approaches are particular- 
ly relevant in European landscapes that have a long history of human influence and limited amounts of protected areas (Mönkkönen et al., 2011). The core areas of reserves would be left out of any management activities except those restorative of natural values. Ecologically-based forest management approaches (Franklin et al., 2007,2018 ) may be the most reasonable way to go when considering limited management zones, forest areas outside national park territories, and forests in younger development stages. Since protected forest areas and managed forests are typically intermingled in all forest landscapes, the maintenance of biodiversity depends on both (Polasky et al., 2005). Incorporating models of natural disturbance and stand development processes more fully into silvicultural practices is the basis for an ecological forestry approach (Franklin et al., 2018), which can benefit both local communities and nature. The scenario that accelerates the development of a complex forest and also increases timber harvests produces increases in the average standard of living in the community, an increase in biodiversity, and an expanded habitat for protected species (Underwood et al., 2014). While some land uses are clearly incompatible with some conservation goals, many elements of biodiversity can readily tolerate at least some level of human disturbance and alteration of the landscape (e.g., Redford \& Richter, 1999; Currie, 2003).

\section{Conclusions}

Stand development classification can be a good tool for describing old-growth forest. Acknowledging specific structural elements helps us better understand the level of previous human influences and the developmental path through which these forests evolve naturally.

If we understand and preserve biological legacies on any forest areas previously subject to even-aged forest management, it should give us confidence that in the long term, ecological forestry actions can help to contribute to increased ecological heterogeneity and biodiversity in these areas. It is not an easy task for conservation and overall landscape planning, because these actions may not be visible in the short term. But by thinking in sustainable terms we take the longer view because forestry actions taken today are not just for today but, most profoundly for future generations.

\section{Acknowledgments}

We thank the team of Metsakorralduse Büroo OÜ for their input related to this study in Lahemaa National Park. We also thank the Estonian Environmental Board for providing us the data and the Estonian Environmental Investment Centre for their funding support. Insightful comments on the manuscript by Russell D. Kramer, R. Keala Hagmann, Linda Winter, James A. Freund, Miles LeFevre and Daniel A. Underwood were greatly appreciated.

\section{References}

Ahti T., Hämet-Ahti L., Jalas J. 1968. Vegetation zones and their sections in northwestern Europe. - Annales Botanici Fennici, 5, 169-211.

Carey, A.B. 2009. Maintaining Biodiversity in Managed Forests. - Spies, T.A., Duncan, S.L. (eds.). Old Growth in a New Word: a Pacific Northwest icon reexamined. Washington, Island Press, 58-69.

Clements, F.E. 1916. Plant Succession: An Analysis of the Development of Vegetation. Washington, Carnegie Institute of Washington, Publication 242.

Council Directive 2009/147/EC. - Directive 2009/147/EC of the European Parliament and of the Council of 30 November 2009 on the conservation of wild birds. [WWW document]. - URL http://eur-lex.europa.eu/ legal-content/EN/TXT/PDF/?uri=CELEX:32 009L0147\&from=EN. [Accessed 1 March 2016].

Council Directive 92/43/EEC. - Council Directive 92/43/EEC of 21 May 1992 on the conservation of natural habitats and of wild fauna and flora. [WWW document] - URL http://eur-lex. 
europa.eu/legal-content/EN/TXT/PDF/?ur

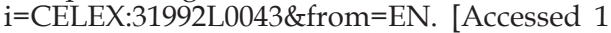
March 2016].

Currie, D.J. 2003. Conservation of endangered species and the patterns and propensities of biodiversity. - Comptes Rendus Biologies, 326 (Supplement 1), 98-103.

EELIS. 2016. Nature Information System (Eesti Looduse Infosüsteem). Estonian Environmental Agency. [WWW document]. URL http://loodus.keskkonnainfo.ee/eelis/. [Accessed 21 March 2016].

Environmental Register. 2017. Environmental Register (Keskkonnaregister). Estonian Environmental Agency. [WWW document]. - URL http://register. keskkonnainfo.ee/envreg/main?regkood=KLO1000511\&mount=view. [Accessed 15 April 2017].

Franklin, J.F., Johnson, K.N., Johnson, D. 2018. Ecological Forest Management. Chicago, Waveland Press. 646 pp.

Franklin, J.F., Lindenmayer, D., MacMahon, J.A., McKee, A., Magnuson, J., Perry, D.A., Waide, R., Foster, D. 2000. Threads of Continuity. Conservation in Practice, 1(1), 8-17.

Franklin, J.F., Mitchell, R.J., Palik, B.J. 2007. Natural Disturbance and Stand Development Principles for Ecological Forestry. General Technical Report NRS-19. United States Department of Agriculture, Forest Service, Northern Research Station. 44 p.

Franklin, J.F., Spies, T.A., Van Pelt, R., Carey, A.B., Thornburgh, D.A., Berg, D.R., Lindenmayer, D.B., Harmon, M.E., Keeton, W.S., Shaw, D.C., Bible, K., Chen, J. 2002. Disturbances and structural development of natural forest ecosystems with silvicultural implications, using Douglas-fir forests as an example. Forest Ecology and Management, 155, 399-423.

Jõgiste, K., Korjus, H., Stanturf, J.A., Frelich, L.E., Baders, E., Donis, J., Jansons, A., Kangur, A., Köster, K., Laarmann, D., Maaten, T., Marozas, V., Metslaid, M., Nigul, K., Polyachenko, O., Randveer, T., Vodde, F. 2017. Hemiboreal forest: natural disturbances and the importance of ecosystem legacies to management. Ecosphere, 8(2), e01706.

Jonsson, B.G., Ekström, M., Esseen, P.-A., Grafström, A., Ståhl, G., Westerlund, B. 2016. Dead wood availability in managed Swedish forests - Policy outcomes and implications for biodiversity. - Forest Ecology and Management, 376, 174-182.

Jonsson, B-G., Kruys, N., Ranius, T. 2005. Ecology of species living on dead wood - Lessons for dead wood management. - Silva Fennica, 39(2), 289-309.

Kalda, A. 1988. Plant cover and geobotanical division of Lahemaa National Park (Lahemaa rahvuspargi taimkate ja selle geobotaanniline liigestus). - Etverk, I. (ed.). Lahemaa uurimused III. Rahvuspargi looduse inventeerimine. Tallinn, Valgus, 68-87. (In
Estonian with English abstract).

Kiviste, A., Hordo, M., Kangur, A., Kardakov, A. Laarmann, D., Lilleleht, A., Metslaid, S., Sims, A., Korjus, H. 2015. Monitoring and modeling of forest ecosystems: the Estonian Network of Forest Research Plots. - Forestry Studies / Metsanduslikud Uurimused, 62, 26-38.

Köster, K., Jõgiste, K., Tukia, H., Niklasson, M., Möls, T. 2005. Variaton and ecological characteristics of coarse woody debris in Lahemaa and Karula National Parks, Estonia. - Scandinavian Journal of Forest Research, 20(6), 102-111.

Laarmann, D. Korjus, H., Sims, A., Kangur, A., Stanturf, J.A. 2013. Initial effects of restoring natural forest structures in Estonia. - Forest Ecology and Management, 304, 303-311.

Lahemaa. 2015. Protection regulations of Lahemaa National Park (Lahemaa rahvuspargi kaitseeeskiri). - Riigi Teataja, RT I, 26.02.2015, 33. (In Estonian).

Larsen, J.A. 1980. The Boreal Ecosystem. New York, Academic Press. 500pp.

Larsen, J.A. 1982. Ecology of the Northern Lowland Bogs and Conifer Forests. New York, Academic Press. 320 pp.

Lindenmayer, D.B., Franklin, J.F. 2002. Conserving Forest Biodiversity: A Comprehensive Multiscaled Approach. Washington, Island Press. 352 pp.

Lindenmayer, D.B., Franklin, J.F., Fischer, J. 2006. General management principles and checklist of strategies to guide forest biodiversity conservation. - Biological Conservation, 131, 433-445.

Looduskaitseseadus. 2004. Nature Conservation Act (Looduskaitseseadus). - RT I, 14.11.2018, 8. (In Estonian).

Lõhmus, A., Kraut, A. 2010. Stand structure of hemiboreal old-growth forests: Characteristic features, variation among site types, and a comparison with FSC-certified mature stands in Estonia. - Forest Ecology and Management, 260(1), 155-165.

Lõhmus, E. 1984. Forests Site Types of Estonia (Eesti metsakasvukohatüübid). Tallinn, Eesti NSV Metsamajanduse ja Looduskaitse Ministeerium. (In Estonian).

Maamets, L. 2012. Report of Lahemaa National Park inventory and value analysis (Lahemaa rahvuspargi metsade inventeerimise ja väärtuste analüüsi seletuskiri). Metsakorralduse Büroo OÜ. (In Estonian).

Metsakorraldus. 2009. Forest management guide (Metsa korraldamise juhend). - RT I, 31.08.2018, 8. (In Estonian).

Metsaseadus. 2006. Forest Act (Metsaseadus). - RT I, 13.03.2019, 61. (In Estonian).

Mönkkönen, M., Reunanen, P., Kotiaho, J.S., Juutinen, A., Tikkanen, O.-P., Kouki, J. 2011. Cost-effective strategies to conserve boreal forest biodiversity and long-term landscapelevel maintenance of habitats. - European Journal of Forest Research, 130, 717-727. 
Nilsson, S.G., Niklasson, M., Hedin, J., Aronsson, G., Gutowski, J.M., Linder, P., Ljungberg, H., Mikusiński, G., Ranius, T. 2003. Erratum to "Densities of large living and dead trees in oldgrowth temperate and boreal forests". - Forest Ecology and Management, 178(3), 355-370.

Paal, J. 1997. Classification of the Estonian vegetation site types (Eesti taimkatte kasvukohatüüpide klassifikatsioon). Tallinn, Keskkonnaministeeriumi Info- ja Tehnokeskus. (In Estonian).

Palo, A. 2010. Habitats Directive forest habitat inventory guide (Loodusdirektiivi metsaelupaikade inventeerimise juhend). [WWW document]. - URL http:/ / www.envir. ee/sites/default/files/metsainventeerimine juhend_2011_2605_lopp.pdf. [Accessed 18 February 2016]. (In Estonian).

Polasky, S., Nelson, E., Lonsdorf, E., Fackler, P., Starfield, A. 2005. Conserving species in a working landscape: land-use with biological and economic objectives. - Ecological Applications, 15, 1387-1401.

Redford, K.H., Richter., B.D. 1999. Conservation of biodiversity in a world of use. - Conservation Biology, 13(6), 1246-1256.

Ritchie, J.C. 1962. A geobotanical survey of northern Manitoba. Technical Paper 9. Montreal, Arctic Institute of North America, $1-46$.

Rouvinen, S., Kuuluvainen, T., Karjalainen, L. 2002. Coarse woody debris in old Pinus sylvestris dominated forests along a geographic and human impact gradient in boreal Fennoscandia. - Canadian Journal of Forest Research, 32, 2184-2200.

Shorohova, E., Kapitsa, E. 2014. Influence of the substrate and ecosystem attributes on the decomposition rates of coarse woody debris in European boreal forests. - Forest Ecology and Management, 315, 173-184.

Sippola, A.-L., Siitonen, J., Kallio, R., 1998. Amount and quality of coarse woody debris in natural and managed coniferous near the timberline in Finnish Lapland. - Scandinavian Journal of Forest Research, 13(1-4), 204-214.

Swanson, M.E., Franklin, J.F., Beschta, R.L., Crisafulli, C.M., DellaSala, D.A., Hutto, R.L., Lindenmayer, D.B., Swanson, F.J. 2011. The Forgotten Stage of Forest Succession: EarlySuccessional Ecosystems on Forest Sites. Frontiers in Ecology and the Environment, 9(2), 117-125.

Thomas, J.W., Ruggiero, L.F., Mannan, R.W., Schoen, J.W., Lancia, R.A. 1988. Management and conservation of old-growth forests in the United States. - Wildlife Society Bulletin, 16, 252-262.

Tikkanen, O-P., Martikainen. P., Hyvärinen, E., Junninen, K., Kouki, J. 2006. Red-listed boreal forest species of Finland: associations with forest structure, tree species and decaying wood. - Annales Zoologici Fennici, 43(4), 373383.

Underwood, D.A., Friesner, D., Cross, J. 2014. Toward an Institutional Legitimation of Sustainability. - Journal of Economic Issues, 48(3), 871-886.

Van Pelt, R. 2007. Identifying Mature and Old Forests in Western Washington. Washington State Department of Natural Resources, Olympia, WA. 104 pp.

Worster, D. 1994. Nature`s Economy: A History of Ecological Ideas (2nd Edition). New York, Cambridge University Press. 507 pp. 


\section{Appendix 1. Development stage classifications}

\section{Lisa 1. Arenguklasside klassifikatsioon}

Table A1.1. Examples of different forest stand development stage classifications in relation to stand age.

Tabel A1.1. Erinevad metsa arenguklasside klassifikatsioonid enamuspuuliigi ja puistu vanuse vôrdluses.

\begin{tabular}{|c|c|c|c|c|c|c|}
\hline \multicolumn{3}{|c|}{$\begin{array}{l}\text { Typical stage years } \\
\text { Tüüpiline puistu vanus } \\
\text { arenguklassis }\end{array}$} & \multicolumn{4}{|c|}{$\begin{array}{l}\text { Stand development stage classifications } \\
\text { Arenguklasside klassifikatsioon }\end{array}$} \\
\hline $\begin{array}{l}\text { Deciduous } \\
\text { Lehtpuud }\end{array}$ & $\begin{array}{c}\text { Norway } \\
\text { spruce } \\
\text { Harilik } \\
\text { kuusk }\end{array}$ & $\begin{array}{c}\text { Scots pine } \\
\text { Harilik } \\
\text { mänd }\end{array}$ & $\begin{array}{l}\text { Forest survey } \\
\text { guidelines } \\
\text { Metsa } \\
\text { korraldamise } \\
\text { juhend } \\
\text { (Metsakorraldus, } \\
\text { 2009) }\end{array}$ & $\begin{array}{l}\text { Simplified stage } \\
\text { model } \\
\text { Lihtsustatud } \\
\text { arenguklasside } \\
\text { mudel (Franklin } \\
\text { et al., 2018) }\end{array}$ & $\begin{array}{l}\text { Eight-stage } \\
\text { model } \\
\text { Kaheksa } \\
\text { arenguklassi } \\
\text { mudel } \\
\text { (Franklin et } \\
\text { al., 2002) }\end{array}$ & $\begin{array}{c}\text { OG Guide } \\
\text { Pôlismetsade } \\
\text { juhend } \\
\text { (Van Pelt, 2007) }\end{array}$ \\
\hline 0 & 0 & 0 & $\begin{array}{l}\text { Temporary } \\
\text { unforested area }\end{array}$ & $\begin{array}{l}\text { Disturbance and } \\
\text { legacy creation }\end{array}$ & $\begin{array}{l}\text { Disturbance } \\
\text { and legacy } \\
\text { creation }\end{array}$ & \\
\hline $1-5$ & $1-5$ & $1-5$ & & Pre-forest & $\begin{array}{c}\text { Cohort } \\
\text { establishment }\end{array}$ & $\begin{array}{l}\text { Cohort } \\
\text { establishment }\end{array}$ \\
\hline $5-15$ & $5-20$ & $5-20$ & $\begin{array}{l}\text { Sapling stage, } \\
\text { young stand. } \\
\text { pole stand }\end{array}$ & Canopy closure & Canopy closure & Canopy closure \\
\hline $15-30$ & $20-40$ & $20-45$ & Middle-age & Youn a forest & $\begin{array}{l}\text { Biomass } \\
\text { accumulation/ }\end{array}$ & $\begin{array}{l}\text { Late canopy } \\
\text { closure and } \\
\text { early Biomass } \\
\text { accumulation/ } \\
\text { stem exclusion }\end{array}$ \\
\hline $30-50$ & $40-70$ & $45-80$ & & roung iorest & $\begin{array}{l}\text { competitive } \\
\text { exclusion }\end{array}$ & $\begin{array}{c}\text { Biomass } \\
\text { accumulation/ } \\
\text { stem exclusion } \\
\text { and early } \\
\text { Maturation I }\end{array}$ \\
\hline $50-60$ & $70-80$ & $80-90$ & Maturing stand & & & Maturation I \\
\hline $60-70$ & $80-90$ & $90-120$ & & Mature forest & Maturation & Maturation II \\
\hline $70-80$ & $90-100$ & & Mature stand & & & \\
\hline $80-90$ & $100-150$ & $120-200$ & & $\begin{array}{l}\text { Old forest (Early } \\
\text { stage) }\end{array}$ & $\begin{array}{c}\text { Vertical } \\
\text { diversification }\end{array}$ & $\begin{array}{c}\text { Vertical } \\
\text { diversification }\end{array}$ \\
\hline $90-150$ & $150-220$ & $200-300$ & & $\begin{array}{l}\text { Old forest (Late } \\
\text { stage) }\end{array}$ & $\begin{array}{l}\text { Horizontal } \\
\text { diversification }\end{array}$ & $\begin{array}{l}\text { Horizontal } \\
\text { diversification }\end{array}$ \\
\hline & & & & & $\begin{array}{l}\text { Pioneer cohort } \\
\text { loss }\end{array}$ & \\
\hline
\end{tabular}




\title{
Vanade loodusmetsade elupaigatüübi inventeerimine Lahemaa rahvuspargis
}

\author{
Teele Paluots, Jerry F. Franklin, Lembit Maamets, Diana Laarmann, \\ Ahto Kangur ja Henn Korjus
}

\section{Kokkuvõte}

Põlismetsade elurikkuse säilitamisel on oluline mõista puistus esinevate struktuurielementide tähendust. Seetõttu on looduskaitsealadel vajalik metsaelupaikade seisundi pidev inventeerimine. Metsakorralduse Büroo OÜ tegi 2010. ja 2011. aastal Natura 2000 metsaelupaikade suuremahulise inventuuri, mis hõlmas $60 \%$ Lahemaa rahvuspargi pindalast. Siinses uurimuses on kasutatud selle inventuuri käigus kogutud andmeid vanade loodusmetsade elupaigatüübi kohta (7191 ha), et analüüsida selle elupaigatüübi puistute seisundit. Andmeid analüüsiti rinnete ja lagupuidu esinemise järgi ning arenguklasside ja esindusklasside järgi. Täpsemateks hinnanguteks kasutati ka Lahemaa rahvuspargis asuva 27 proovitüki andmeid Eesti metsa kasvukäigu püsiproovitükkide võrgustiku andmetest. Lahemaa rahvuspargis on vanade loodusmetsade elupai- gatüübis suurema pindalaga küpse metsa ja vana metsa arenguklassid. Lagupuidu esinemine (üle $5 \mathrm{~m}^{3} \mathrm{ha}^{-1}$ ) oli sagedasem põlismetsa ja loodusmetsa esindusklassides. Üllatuslikult ei esinenud nimetatud koguses lagupuitu 32\%-1 põlismetsade esindusklassi kuuluvate puistute pindalast. Seega tõenäoliselt ei ole sellistel aladel piisavalt mitmesuguseid elupaiganišše erinevatele looma- ja taimeliikidele. Siinne uurimus kinnitas varasemate uurimuste tulemusi lagupuidu koguste kohta siinse regiooni looduskaitsealadel. Samas oleks võimalik looduskaitsealadel loodusväärtust suurendada rakendades mitmesuguseid ökoloogilise taastamise võtteid. Püstiseisvate surnud puude, tüügaste, lamapuidu ja teiste struktuurielementide kunstlik tekitamine suurendab metsaökosüsteemisisest ruumilist varieeruvust ja korduvate võtetega saab tagada pideva lagupuidu voo ning seeläbi tekitada lagupuidu erinevaid kõdunemisastmeid. 